\title{
Factors influencing trust in university websites: A survey amongst Generation Y students in South Africa
}

\author{
Marko van Deventer \\ North-West University, South Africa \\ Heleneze-Tianè Lues \\ North-West University, South Africa
}

\section{Keywords}

Generation Y students, information quality, system quality, trust, university, website

\begin{abstract}
Considering the growing number of Generation Y students enrolled at South African higher education institutions (HEIs), and university websites primarily being the first point of reference in sourcing and evaluating information about the university and the courses offered, as well as Generation $Y$ students' scepticism about marketing tactics and their low trust propensity, it is imperative to understand the factors that influence this generation's trust in university websites. As such, the purpose of this study was to determine the influence of perceived system and information quality on Generation Y students' trust in university websites within the South African context. A single cross-sectional and descriptive research design was followed in this study. A self-administered questionnaire was designed to collect data from a convenience sample of 319 Generation Y students registered at two Gauteng-based South African HEI campuses. The methods used to analyse the data included descriptive statistics, Pearson's product-moment correlation analysis, reliability measures, regression analysis and collinearity diagnostics. The findings of the study suggest that Generation Y students' perceived information and system quality of university websites has a significant positive influence on their perceived trust in university websites. Insights gained from this study can assist universities in devising appropriate strategies that will foster trust in their website, thereby paving the way forward for an increased number of visitors and student enrolments.
\end{abstract}

Corresponding author: Marko van Deventer

Email addresses for the corresponding author: Marko.VanDeventer@nwu.ac.za

First submission received: $19^{\text {th }}$ June 2018

Revised submission received: $30^{\text {th }}$ August 2018

Accepted: $3^{\text {rd }}$ November 2018

\section{Introduction}

The $21^{\text {st }}$ century's digital technologies, such as the internet and its supporting tools, are continuously introducing new ways in which organisations and people interact (Ganiyu, Mishra, Elijah \& Gana, 2017). These technologies, in general, and websites, in particular, provide an organisation with the opportunity to tap into global markets, reach a larger audience, communicate with its stakeholders, as well as improve the operational efficiency and image of the organisation (Ganiyu et al., 2017; Mentes \& Turan, 2012). As such, websites are an essential tool for surviving in both the highly competitive local and global markets (Mentes \& Turan, 2012). Approximately two billion websites are available on the Internet and more are developed on a daily basis, which demonstrates that more organisations, including universities, recognise the importance of having a well-developed website (InternetLiveStats, 2018). For universities, websites serve as a valuable communication tool (Bairamzadeh \& Bolhari, 2010) and are considered the source most used to access university-related content (Buang et al., 2016). Therefore, universities are increasingly dependent on their websites to function as an information provider (ElHalees \& Abu-Zaid, 2017).

Not only are websites increasing in numbers on a daily basis, but the numbers of internet users and the time they spend on the Internet are also increasing. In January 2018, more than half of the world's population of close to 7.6 billion were active users of the internet. This is seven percent more compared to 
January 2017. In South Africa, there were 30.81 million internet users in January 2018, which are 54 percent of South Africa's total population and an increase of seven percent from 2017. This number is expected to increase during 2018. Currently, these users spend an average of approximately eight and a half hours on the internet per day (McDonald, 2018). Of these internet users, a staggering 65.77 percent are represented by the Generation Y cohort (MyBroadband, 2018).

The Generation Y cohort, also known as the millennials or the internet generation (Severt, Fjelstul \& Breiter, 2013), includes those individuals born between 1986 and 2005 (Markert, 2004). Individuals of this cohort are characterised as being independent, self-reliant, confident, and well educated (Broadbridge, Maxwell \& Ogden, 2007). Compared to previous generations, Generation $Y$ is the first generation with access to several multimedia platforms, mobile phones, convergent technologies and the internet (Schlitzkus, Schenarts \& Schenarts, 2010), rendering them the most technologically astute generation to date. As part of their daily lives, Generation Y enjoys browsing the internet (Bilgihan, 2016) and playing on social networking sites (Severt et al., 2013). This digitally connected generation frequently uses the internet to find information that could assist with their decision-making (Valentine \& Powers, 2013). From a marketing perspective, literature suggests that Generation $Y$ customers are sceptical of the media and of online content that feels generic or like a sales pitch (Ali, 2015; Bubser, 2016). As such, traditional online marketing has proven to be less effective (Colucci \& Cho, 2014). St Louis (2017) agrees and states that Generation Y customers' dismissive attitude towards traditional online marketing efforts could be due to the lack of trust in an organisation.

Trust within an online context plays an important role. This is because the customer has no direct control over the actions of the product or service provider (Muda, Mohd \& Hassan, 2016). In addition, the internet increases organisations' interpersonal distance from their customers, which may also create trust issues (Benamati \& Serva, 2007). Therefore, it comes as no surprise that one of the main reasons why customers avoid engaging in online undertakings is due to the lack of trust (Muda et al., 2016). For any website to be considered successful, it is important that users perceive it as trustworthy (Bilgihan, 2016). Trust refers to an individual's confidence in another entity's conduct when the individual is in a vulnerable position or has no control over the other entity (Hosmer, 1995; Lewicki, Mcallister \& Bies, 1998). Trust is also defined as an individual's psychological expectations that a trusted party will not behave opportunistically (Kim, Shin \& Lee, 2009). A number of studies related to the quality of a website within specific contexts, namely online auctions (Gregg \& Walczak, 2010), online hotel bookings (Lien, Wen, Huang \& Wu, 2015) and consumer-generated media (Filieri, Alguezaui \& McLeay, 2015) found that website quality has a significant positive influence on trust in these websites. Various other online studies (Hsiao, Lin, Wang, Lu \& Yu, 2010; Kim, Xu \& Koh 2004; Zhou \& Zhang, 2009) also validate the relationship between website quality and trust in the website. These findings suggest that high website quality is associated with greater trust in a website, which, in turn, is likely to translate into customers perceiving the product and service provider as competent, honest and benevolent (Liang \& Chen, 2009). In terms of university websites, two particularly important aspects contribute to the overall quality of the website and subsequently foster greater trust, namely the system and information quality of the website.

Considering the growing number of Generation $\mathrm{Y}$ students enrolled at South African higher education institutions (HEIs), and university websites primarily being the first point of reference in sourcing and evaluating information about the university and the courses offered, as well as Generation $Y$ students' scepticism about marketing tactics and their low trust propensity, it is imperative to understand the factors that influence this generation's trust in university websites. As such, the purpose of this study was to determine the influence of perceived system and information quality on Generation Y students' trust in university websites within the South African context.

\section{Literature review System quality}

Perceived system quality is defined as customers' opinions of a website's performance in terms of information delivery and retrieval (Yang, Cai, Zhou \& Zhou, 2005). System quality refers to the consistency of a website's interface and ease of navigation. Difficult website navigation is one of the main barriers of many online undertakings. A well-designed website that is easy to navigate will enhance 
customer experience and satisfaction and will ultimately lead to trust in and the success of the website (Kuan, Bock \& Vathanophas, 2008). As such, customers assess the system-based qualities of a website to determine whether the product or service provider is trustworthy (Kim et al., 2004). A website with adequate system quality and technicalities will enhance the convenience to users and increase customers' confidence and trust in the organisation (Liang \& Chen, 2009). It is therefore recommended that organisations invest considerable time and effort in designing a website that contains effective link structures and interfaces, ultimately making the website user-friendly and trustworthy (Kuan et al., 2008). Other factors that contribute to the system quality of a website include the security of the website (Ahn, Ryu \& Han, 2007) as well as several appearance factors, namely the lay-out of the website, text fonts, colours and the graphics-text balance (Aladwani \& Palviab, 2002). As such, system quality is observable in a website's overall performance (Lin, 2007). These contributing factors hold especially true for Generation $\mathrm{Y}$ customers and students, as they grew up with technology and expect a website to have certain aesthetics and functionality (Djamasbi, Siegel \& Tullis, 2010). With reference to university websites, system quality represents the university website's ability to provide suitable functions controllable by the user or student (Lin, 2010).

In their study, Kim et al. (2004) found that while system quality did not have a direct influence on repeat customers' trust in an internet store, system quality did positively influence repeat customers' trust through customer satisfaction. However, the Zhou and Zhang (2009) study found that system quality has a significant positive influence on trust in the e-commerce websites that the respondents were most familiar with. In terms of mobile banking, Van Deventer, De Klerk and Bevan-Dye (2017) reported that system quality has a statistically significant positive influence on trust in mobile banking, specifically amongst Generation Y customers. In addition, a study on the impact of website quality on customer relationships with online financial services reports that perceived system quality positively influences customers' trust in an online service provider (Liang \& Chen, 2009). Consistent with the findings of these studies, the following hypothesis was developed:

H1: System quality positively influences Generation Y students' trust in university websites.

\subsection{Information quality}

Customers look to websites and the quality of the information provided on these websites to differentiate between providers of similar products or services. It is the information provided on the website that attracts new customers and retains existing ones; therefore, sufficient information quality is positively associated with the success of a website (Kuan et al., 2008). Similar to the system quality of a website, customers evaluate the information-based qualities of a website to evaluate whether a product or service provider can be trusted (Kim et al., 2004). Consequently, if the information on the website is incomplete or inaccurate, it may create trust issues (Liang \& Chen, 2009). For this reason, deciding on which information to display on the website is one of the most important decisions any organisation can make (Rahimnia \& Hassanzadeh, 2013). Perceived information quality refers to the customers' perceptions of the quality of the information provided on an online platform (Yang et al., 2005). Some of the most common determinants of information quality are the accuracy, timeliness, detail and reliability of the information (Ahn et al., 2007). Accuracy signifies the correctness of the information, whereas timeliness reflects how up to date the information is. Detail refers to the completeness of the information and whether all the necessary information was provided (Lin, 2010), while reliability refers to the dependability and consistency of the information (Yang et al., 2005). In terms of university websites, information quality would typically refer to the relevance, accurateness and timeliness of information relating to courses, modules, online registrations and other learning content (El-Halees \& Abu-Zaid, 2017; Lin, 2010).

Literature suggests that information quality influences trust amongst customers. In a study conducted by Kim et al. (2004), it was found that information quality positively influences potential and repeat customers' trust in an internet store. Similarly, Zhou and Zhang (2009) report that information quality significantly affects trust in e-commerce websites. Although Nilashi, Jannach, bin Ibrahim, Esfahani and Ahmadi (2016) did not determine information quality's direct influence on trust, their 
findings suggest that information quality positively influences website quality, which, in turn, positively influences customers' trust in two popular e-commerce websites, namely Amazon and Lazada. In terms of the effectiveness of e-marketing of Iranian commercial saffron corporations, Rahimnia and Hassanzadeh (2013) report that information quality has a significant positive effect on trust. In addition, Filieri et al. (2015) found that information quality positively influences customers' trust in websites that provide consumer-generated content, such as TripAdvisor. In accordance with the findings of these studies, the following hypothesis was developed:

H2: Information quality positively influences Generation Y students' trust in university websites.

\section{Research model}

Existing theoretical and empirical studies accentuate the importance of trust in websites. The proposed research model, as displayed in Figure 1, examines the influence of perceived system quality and information quality on Generation Y students' trust in university websites within a South African context. Consistent with the literature, both system quality and information quality are presumed to have a direct positive influence on trust in university websites.

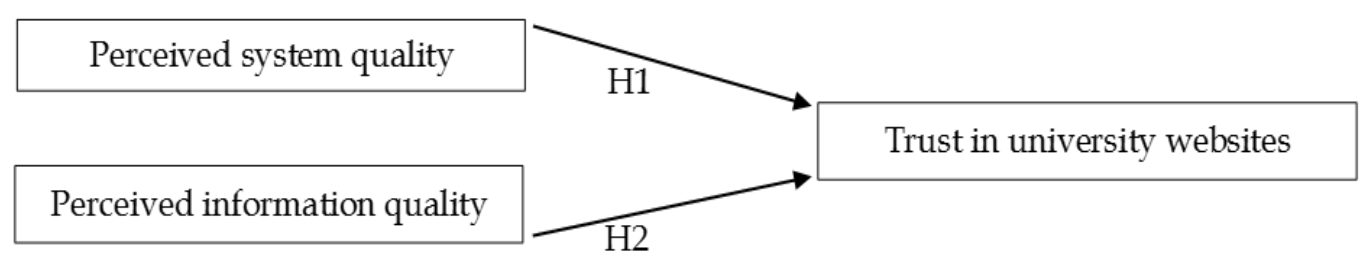

Figure 1: Research model

\section{Research methodology}

\subsection{Research design and approach}

This study involved the observation and description of a subject's behaviour without influencing it in any manner. In addition, the data were collected from a single sample only once, meaning that only one sample of participants was drawn from the target population, and that the information was obtained from this sample only once to provide a snapshot of the population at a certain time. As such, a descriptive and single cross-sectional research design was followed in this study.

\subsection{Research instrument}

A self-administered questionnaire was designed to collect the data for this study. The questionnaire comprised a cover letter that explained the primary objective of the study and guaranteed the protection of the participants in terms of the information provided. In line with the data required for this study, scaled items from published studies were adapted to reflect trust in university websites. The perceived information quality of university websites was measured using five items, namely 'My university website provides relevant information', 'My university website provides accurate information', 'My university website provides reliable information', 'My university website provides information that is up-to-date', and 'My university website provides complete and sufficient information' (Ahn et al., 2007). Perceived system quality was measured using six items, namely 'My university website is up and running all the time', 'My university website has good functionality', 'My university website has a logical layout', 'My university website uses fonts properly', 'My university website uses colours properly', and 'The homepage of my university website makes it easy for me to understand clearly how to proceed' (Aladwani \& Palvia, 2002; Ahn et al., 2007; Sindhuja \& Dastidar, 2009). Trust in university websites was measured using eight items, namely 'My university website usually fulfils the commitments it takes on', 'My university website does not make false statements', 'My university website is characterised by the honesty and clarity of the services/courses offered', 'My university website is concerned with the present and future interests of its users', 'My university website takes into account the repercussions that its actions could have on the user', 'The information my university website provides is sincere and honest', 'I have confidence in the promises my university website makes', and 'The advice and recommendations given on my university website are made in search of mutual benefit' (Flavián, Guinalíu \& Gurrea, 2006).

www.jbrmr.com A Journal of the Academy of Business and Retail Management (ABRM) 
All scaled responses were anchored on a six-point Likert-type scale that ranged from strongly disagree (1) to strongly agree (6). The questionnaire also included a section to collect demographic information of the participants.

\subsection{Participants}

The population targeted for this study was Generation Y students between the ages of 18 and 24 years, registered at public HEIs in South Africa. The sampling frame included the 26 South African public HEIs, which were narrowed down to a judgement sample of two Gauteng-based HEI campuses - a traditional university campus and a university of technology campus. The Gauteng province was selected primarily because it is the most populated province in South Africa and the province with the highest percentage of student enrolment in public HEIs (Department of Higher Education and Training, 2018). Owing to the Protection of Personal Information (POPI) Act that was enacted in South Africa in 2013, it was not possible to obtain a list of all the students registered at the participating campuses and access their personal information without gaining their consent first. As a result, the possibility of using a probability sampling method for data collection was eliminated. As such, the questionnaires were distributed to a non-probability convenience sample of 400 students across the two campuses. Of the 400 questionnaires distributed, 319 were complete and suitable for statistical analysis, which equates to a response rate of nearly 80 percent.

In accordance with the defined target population, all age groups were included in the sample. The sample comprised more female students than males, and the majority of the students were in their first year of study. In terms of ethnicity, the majority of the students were black, followed by white students. In 2018, the total South African population amounted to 57 million people, of which approximately 35 percent formed part of the Generation Y cohort. Of the 35 percent, a staggering 84 percent were accounted for by black individuals, compared to the coloured portion accounting for roughly 8 percent and the white portion 5 percent (Statistics South Africa, 2018). In line with these statistics, the largest portion of the sample was black participants. Furthermore, the sample comprised students from eight of South Africa's nine provinces, and each of South Africa's 11 official language groups. A description of the sample can be found in Table 1.

\begin{tabular}{llllll}
\hline & Percent $(\%)$ & & Percent $(\%)$ & Percent $(\%)$ \\
\hline Age & & Language & & Province & \\
18 & 20.4 & Afrikaans & 6.9 & Eastern Cape & 3.1 \\
19 & 17.2 & English & 5.3 & Free State & 10.3 \\
20 & 24.1 & isiNdebele & 2.2 & Gauteng & 51.4 \\
21 & 16.0 & isiXhosa & 6.6 & KwaZulu-Natal & 2.5 \\
22 & 11.3 & isiZulu & 13.8 & Limpopo & 18.2 \\
23 & 6.6 & Sepedi & 12.2 & Mpumalanga & 9.1 \\
24 & 4.4 & Sesotho & 24.8 & Northern Cape & 0.3 \\
Gender & & Setswana & 10.3 & North West & 5.0 \\
Female & 51.4 & SiSwati & 4.7 & Year of study & \\
Male & 48.6 & Tshivenda & 5.3 & 1st year & 50.2 \\
Ethnicity & & Xitsonga & 7.5 & 2nd year & 11.0 \\
Black & 88.1 & Institution & & 3 & 26.8 \\
Coloured & 2.5 & Traditional & 55.2 & 4. & 10.7 \\
Asian & 0.6 & Technology & 44.8 & Post-graduate & 1.3 \\
White & 8.8 & & & & \\
\hline
\end{tabular}

Table 1: Sample description

\subsection{Data collection procedure}

Permission to distribute the questionnaires was solicited from each of the two HEI campuses. Once permission was obtained, two students trained as fieldworkers distributed the questionnaires at each of the two campuses for voluntary completion using the mall-intercept survey method. The criteria used to 
select the sample elements included the student's age and registration, since the student had to form part of the Generation Y cohort and had to be registered at one of the participating campuses. Students were duly informed that participation in the study was on a voluntary basis only and that the confidentiality of any information provided would be assured.

\subsection{Data analysis}

The collected data were analysed using the Statistical Package for Social Sciences (IBM SPSS), Version 24 for Windows. Data analysis included descriptive statistics, reliability measures, correlation and multivariate regression analysis as well as collinearity diagnostics.

\section{Results}

\subsection{Descriptive statistics, reliability and correlation analysis}

As part of the descriptive statistics, the means and standard deviations were calculated for each construct. Moreover, the internal-consistency reliability of each construct was assessed by calculating the Cronbach's alphas. To determine the relationships between the constructs, a correlation matrix of Pearson's product-moment correlation coefficients was constructed. The descriptive statistics, reliability measures and correlation coefficients are reported in Table 2.

\begin{tabular}{llllllll}
\hline Constructs & & Means & Standard deviations & Cronbach's alphas & F1 & F2 & F3 \\
\hline Trust & (F1) & 4.405 & 0.898 & 0.887 & 1 & $0.551^{*}$ & $0.670^{*}$ \\
Information quality & (F2) & 4.564 & 0.877 & 0.862 & & 1 & $0.492^{*}$ \\
System quality & (F3) & 4.433 & 0.901 & 0.800 & & & 1 \\
\hline
\end{tabular}

"Statistically significant at $\mathrm{p}<0.01$

Table 2: Descriptive statistics, reliability measures, and correlation coefficients

As indicated in Table 2, a mean value above 4.5 was calculated for each construct. Based on the sixpoint Likert-type scale used, these results suggest that South African Generation Y students trust that university websites do not make false statements, are honest and clear in all information provided, and trust that all statements on university websites are made in search of a mutual benefit. Furthermore, the sample believes that the information provided on university websites is relevant, easily understandable, accurate, sufficient and reliable. Moreover, the students perceive university websites as having good functionality, a logical layout and that it uses fonts and colours properly.

Each construct returned a Cronbach's alpha value above the recommended 0.70 level (Hair, Black, Babin \& Anderson, 2010), which infers that the scales used in this study encompass good internalconsistency reliability. In terms of the relationships observed between the constructs, the results in Table 2 show that there were statistically significant $(p \leq 0.01)$ positive associations between each pair of constructs, which is indicative of the nomological validity of the measurement theory (Malhotra, 2010). Furthermore, the correlation coefficients were all below 0.90, suggesting that there were no obvious signs of multicollinearity (Hair et al., 2010).

\subsection{Regression analysis}

Multivariate regression analysis was conducted to examine the influence of the two independent variables, namely perceived information quality, and system quality on the dependent variable, namely perceived trust in university websites. Table 3 delineates the regression model summary and ANOVA results.

\begin{tabular}{llllll}
\hline Regression model & $\mathrm{R}$ & $\mathrm{R}^{2}$ & Adjusted $\mathrm{R}^{2}$ & $\mathrm{~F}$ & $\mathrm{p}$-value \\
\hline Model 1 & 0.717 & 0.514 & 0.511 & 167.383 & 0.000 \\
\hline
\end{tabular}

Table 3: Regression model summary and ANOVA results 
The significant F-ratio in Table 3 suggests that the regression model predicts trust in university websites. The adjusted $\mathrm{R}^{2}$ value signifies that approximately 51 percent of the variance in Generation $\mathrm{Y}$ students' trust in university websites is explained by perceived information and system quality. The amount of variance explained infers that there are other factors that influence trust in university websites amongst Generation Y students, which need to be investigated in future studies.

The contribution that each of the independent variables makes to the prediction of trust in university websites was subsequently assessed, as shown in Table 4.

\begin{tabular}{llllllll}
\hline $\begin{array}{l}\text { Independent } \\
\text { variables }\end{array}$ & $\begin{array}{l}\text { Standardised } \\
\text { beta coefficient }\end{array}$ & t-value & Sig & Hypothesis & $\begin{array}{l}\text { Hypothesis } \\
\text { testing } \\
\text { result }\end{array}$ & \multicolumn{2}{l}{$\begin{array}{l}\text { Collinearity } \\
\text { statistics }\end{array}$} \\
\cline { 6 - 8 } & & & & & Tolerance & VIF \\
\hline $\begin{array}{l}\text { Information } \\
\text { quality }\end{array}$ & 0.293 & 6.501 & $0.000^{*}$ & H1 & Supported & 0.758 & 1.319 \\
System quality & 0.527 & 11.698 & $0.000^{*}$ & H2 & Supported & 0.758 & 1.319 \\
\hline
\end{tabular}

"Statistically significant at $\mathrm{p}<0.05$ (2-tailed)

Table 4: Contribution of independent variables to predicting trust in university websites and hypothesis testing results

Table 4 and Figure 2 show that perceived information quality $(\beta=0.293, p<0.05)$ and system quality of university websites $(\beta=0.527, \mathrm{p}<0.05)$ have a significant positive influence on Generation $Y$ students' trust in university websites, which supports hypotheses H1 and H2. Of the two, perceived system quality makes the strongest unique contribution towards explaining trust in university websites. With regard to collinearity, the tolerance values for each of the variables were above the 0.10 cut-off level, and the average variance inflation factor (VIF) was well below the cut-off of 10 (Pallant, 2010). These statistics indicate that there is no evidence of multicollinearity between the variables.

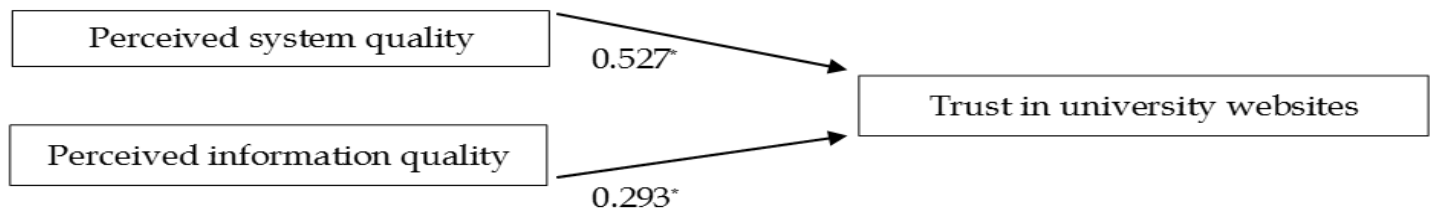

*Significant at the 0.05 level

\section{Managerial implications}

Figure 2: Hypothesis testing results

The purpose of this study was to determine the influence of perceived information and system quality on Generation Y students' trust in university websites within a South African context. The findings of the study suggest that information and system quality are positively correlated with trust in university websites. In addition, in accordance with the literature, the study found that both information and system quality are positive predictors of trust in university websites. Of the two, system quality was found to be the strongest predictor of trust in university websites amongst Generation Y students.

Given the significant contribution that system quality makes to explain trust in university websites, it is important that universities invest considerable time and effort in identifying aspects that could improve the system quality of their websites. The primary purpose of a university's homepage is to encourage users to dig deeper into the website. Therefore, instead of a default and impersonal homepage, universities could consider giving their website users the option of customising their own homepage, allowing them to turn off or on any section of the default homepage. In doing so, users are likely to develop a positive perception of the website's functionality and layout, which, in turn, could bolster their trust in the website. In addition, it is recommended that universities should avoid cramming too much visuals and text into small spaces. The negative space on the website should be embraced and given room to breathe and assist users with finding content better. Universities are also advised to replace paragraphs of information and updates everywhere on the website with high definition images paired with bite-sized 
chunks of text. The images used should be authentic, reflect the university's values and priorities, and represent what it is like to study at the university. Hover effects are excellent tools to use to display the bite-sized chunks of text. By uncluttering the content of a university's website, users are in a better position to find the information they are looking for and understand it more clearly. Universities may also want to concentrate on providing age-appropriate content that is clear and easy to understand. An effective way to appeal to young adults, such as Generation Y students, and to speak their language, is to allow students of the university to do the talking. Content developed by students for prospective and current students can be more engaging, conversational and authentic. As an additional reward, the university sends a message that demonstrates its trust in its students and that their insights are valued. This improved information quality could strengthen a user's trust in the university's website.

\section{Limitations and future research}

One limitation of this study is that data were collected from two universities only. As such, the findings of this study are not a complete representation of all Generation Y students in South Africa. Therefore, due care should be taken in generalising the results to the wider South African Generation $Y$ cohort. Moreover, this study only provides a snapshot in time given the single cross-sectional research design used. Future research that uses a longitudinal research design could be conducted. In addition, a comparative study could be undertaken to observe any differences between the respective South African universities and other demographic variables.

\section{Conclusion}

This study concluded that Generation Y students' perceived information and system quality of university websites have a significant positive influence on their perceived trust in university websites. Insights gained from this study can assist universities in devising appropriate strategies that will foster trust in their website, thereby paving the way forward for an increased number of visitors and student enrolments.

\section{References}

Ahn, T., Ryu, S. \& Han, I. (2007). The impact of web quality and playfulness on user acceptance of online retailing. Information \& Management, 44, 263-275.

Aladwani, A.M. \& Palvia, P.C. (2002). Developing and validating an instrument for measuring user-perceived web quality. Information \& Management, 39(6), 467-476.

Ali, H. (2015). 12 Rules to Engaging the Millennials. https://blog.logodesignguru.com/rules-to-engage-millennials/. [Accessed 2018/06/07].

Bairamzadeh, S. \& Bolhari, A. (2010). Investigating factors affecting students' satisfaction of university websites. (In Computer Science and Information Technology (ICCSIT): 2010 3rd IEEE International Conference, Chengdu, China. New York: IEEE. p. 469-473).

Benamati, J.S. \& Serva, M.A. (2007). Trust and distrust in online banking: their role in developing countries. Information Technology for Development, 13(2), 161-175.

Bilgihan, A. (2016). Gen Y customer loyalty in online shopping: An integrated model of trust, user experience and branding. Computers in Human Behavior, 61, 103-113.

Broadbridge, A.M., Maxwell, G.A. \& Ogden, S.M. (2007). 13_2_30: experiences, perceptions and expectations of retail employment for Generation Y. Career Development International, 12(6), 523-544.

Buang, R.R., Majid, M.K., Wahab, M.I.A., Tohid, M.Z.W.M., Abdullah, A., Adrutdin, K.F., Yacob, S. \& Zahid, M.M. (2016). Factors Affecting Students' Intention to Study at Higher Learning Institution of Technical and Vocational Education and Training. Australasian Journal of Business, Social Science \& Information Technology, 2(1), 19-33.

Bubser, L. (2016). Top 5 Ways to Reach Millennials.

https://www.sightpathmedical.com/news_events/blog/2016/01/14/323/top_5_ways_to_reach_millennials. [Accessed 2018/06/07].

Colucci, C. \& Cho, E. (2014). Trust inducing factors of Generation Y blog-users. International Journal of Design, 8(3), 113-122.

Department of Higher Education and Training see South Africa. Department of Higher Education and Training.

Djamasbi, S., Siegel, M. \& Tullis, T. (2010). Generation Y, web design, and eye tracking. International Journal of HumanComputer Studies, 68, 307-323. 
El-Halees, A. \& Abu-Zaid, I.M. (2017). Automated Usability Evaluation on University Websites using Data Mining Methods. Palestinian Journal of Open Education, 6(11), 13-21.

Filieri, R., Alguezaui, S. \& McLeay, F. (2015). Why do travelers trust TripAdvisor? Antecedents of trust towards consumer-generated media and its influence on recommendation adoption and word of mouth. Tourism Management, 51, 174-185.

Flavián, C., Guinalíu, M. \& Gurrea, R. (2006). The role played by perceived usability, satisfaction and consumer trust on website loyalty. Information \& Management, 43(1), 1-14.

Ganiyu, A.A., Mishra, A., Elijah, J. \& Gana, U.M. (2017). The Importance of Usability of a Website. The IUP Journal of Information Technology, 13(3), 27-35.

Gregg, D.G. \& Walczak, S. (2010). The relationship between website quality, trust and price premiums at online auctions. Electronic Commerce Research, 10(1), 1-25.

Hair, J.F., Black, W.C., Babin, B.J. \& Anderson, R.E. (2010). Multivariate data analysis: a global perspective. New Jersey: Pearson Prentice Hall.

Hosmer, L.T. (1995). Trust: The connecting link between organizational theory and philosophical ethics. The Academy of Management Review, 20(2), 379-403.

Hsiao, K.L., Lin, J.C.C., Wang, X.Y., Lu, H.P. \& Yu, H. (2010). Antecedents and consequences of trust in online product recommendations: An empirical study in social shopping. Online Information Review, 34(6), 935-953.

InternetLiveStats. (2018). Total number of Websites. http://www.internetlivestats.com/total-number-ofwebsites/\#sources. [Accessed 2018/06/11].

Kim, G., Shin, B. \& Lee, H.G. (2009). Understanding dynamics between initial trust and usage intentions of mobile banking. Information Systems Journal, 19(3), 283-311.

Kim, H.W., Xu, Y. \& Koh, J. (2004). A comparison of online trust building factors between potential customers and repeat customers. Journal of the Association for Information Systems, 5(10), 392-420.

Kuan, H.H., Bock, G.W. \& Vathanophas, V. (2008). Comparing the effects of website quality on customer initial purchase and continued purchase at e-commerce websites. Behaviour \& Information Technology, 27(1), 3-16.

Lewicki, R.J., McAllister, D.J. \& Bies, R.J. (1998). Trust and distrust: New relationships and realities. The Academy of Management Review, 23(3), 438-458.

Liang, C.J. \& Chen, H.J. (2009). A study of the impacts of website quality on customer relationship performance. Total Quality Management, 20(9), 971-988.

Lien, C.H., Wen, M.J., Huang, L.C. \& Wu, K.L. (2015). Online hotel booking: The effects of brand image, price, trust and value on purchase intentions. Asia Pacific Management Review, 20, 210-218.

Lin, H.F. (2007). The impact of website quality dimensions on customer satisfaction in the B2C e-commerce context. Total Quality Management \& Business Excellence, 18(4), 363-378.

Lin, H.F. (2010). An application of fuzzy AHP for evaluating course website quality. Computers $\mathcal{E}$ Education, 54(4), 877888.

Malhotra, N.K. (2010). Marketing research: an applied orientation. New Jersey: Pearson Prentice Hall.

Markert, J. (2004). Demographics of age: generational and cohort confusion. Journal of Current Issues E Research in Advertising, 26(2), 11-25.

McDonald, N. (2018). Digital in 2018: World's internet users pass the 4 billion mark. https://wearesocial.com/us/blog/2018/01/global-digital-report-2018. [Accessed 2018/06/03].

Mentes, S.A. \& Turan, A.H. (2012). Assessing the usability of university websites: an empirical study on Namik Kemal University. The Turkish Online Journal of Educational Technology, 11(3), 61-69.

Muda, M., Mohd, R. \& Hassan, S. (2016). Online purchase behavior of Generation Y in Malaysia. Procedia Economics $\mathcal{E}$ Finance, 37, 292-298.

MyBroadband. (2018). What we know about Internet users in South Africa. https://mybroadband.co.za/news/internet/251063-what-we-know-about-internet-users-in-south-africa.html. [Accessed 2018/06/03].

Nilashi, M., Jannach, D., bin Ibrahim, O., Esfahani, M.D. \& Ahmadi, H. (2016). Recommendation quality, transparency, and website quality for trust-building in recommendation agents. Electronic Commerce Research $\mathcal{E}$ Applications, 19, 70-84.

Rahimnia, F. \& Hassanzadeh, J.F. (2013). The impact of website content dimension and e-trust on e-marketing effectiveness: The case of Iranian commercial saffron corporations. Information E Management, 50(5), $240-247$.

Schlitzkus, L.L., Schenarts, K.D. \& Schenarts, P.J. (2010). Is your residency program ready for Generation Y? Journal of Surgical Education, 67(2), 108-111.

Severt, K., Fjelstul, J. \& Breiter, D. (2013). Information communication technologies: Usages and preferences of Generation Y students and meeting professionals. Journal of Convention E Event Tourism, 14(2), 124-143. 
Sindhuja, P.N. \& Dastidar, S.G. (2009). Impact of the factors influencing website usability on user satisfaction. The IUP Journal of Management Research, 3(12), 54-66.

South Africa. Department of Higher Education and Training. (2018). Statistics on post-school education and training in South Africa: 2016. http://www.dhet.gov.za/DHET\%20Statistics\%20Publication/Statistics\%20on \%20PostSchool\%20Education\%20and\%20Training\%20in\%20South\%20Africa\%202016.pdf. [Accessed 2018/09/19].

St Louis, M. (2017). Here's Why Millennials Are Ignoring Your Brand (And What to Do About It). https:/ / www.inc.com/molly-reynolds/heres-why-millennials-are-ignoring-your-brand-and-what-to-doabout-it.html. [Accessed 2018/05/29].

Statistics South Africa. (2018). Mid-year population estimates: 2018, Statistical release P0302. http:/ / www.statssa.gov.za/publications/P0302/P03022018.pdf. [Accessed 2018/09/23].

Valentine, D.B. \& Powers, T.L. (2013). Online product search and purchase behavior of Generation Y. Atlantic Marketing Journal, 2(1), 76-91.

Van Deventer, M., De Klerk, N. \& Bevan-Dye, A. (2017). Influence of perceived integrity and perceived system quality on Generation Y students' perceived trust in mobile banking in South Africa. Banks E Bank Systems, 12(1), 128134.

Yang, Z., Cai, S., Zhou, Z. \& Zhou, N. (2005). Development and validation of an instrument to measure user perceived service quality of information presenting web portals. Information $\mathcal{E}$ Management, 42(4), 575-589.

Zhou, T. \& Zhang, S. (2009). Examining the effect of e-commerce website quality on user satisfaction. (In Electronic Commerce and Security (ISECS): 2009 2nd International Symposium, Nanchang, China. New York: IEEE. p. 418-421). 